\title{
DIABETES MELITUS TIPE 2: FAKTOR RISIKO, DIAGNOSIS, DAN TATALAKSANA
}

\author{
Kadek Resa Widiasari' ${ }^{1}$, I Made Kusuma Wijaya², Putu Adi Suputra ${ }^{3}$ \\ ${ }^{1}$ Prodi Kedokteran, Universitas Pendidikan Ganesha \\ ${ }^{2}$ Prodi Kedokteran, Universitas Pendidikan Ganesha \\ ${ }^{3}$ Prodi Kedokteran, Universitas Pendidikan Ganesha \\ e-mail: resa.widiasari@undiksha.ac.id, kusuma.wijaya@undiksha.ac.id, \\ dr.adisuputra@gmail.com
}

\begin{abstract}
Abstrak
Diabetes melitus menggambarkan sekelompok penyakit metabolik yang temuan umumnya adalah kadar glukosa darah yang meningkat. Pada usia 20-79 tahun, terdapat 463 juta atau setara $9,3 \%$ orang di dunia menderita diabetes pada tahun 2019 . Penulisan artikel ini menggunakan metode literature review dan diharapkan dapat dijadikan acuan kedepan dalam melakukan tindakan pencegahan dan pengobatan pasien diabetes melitus sehingga prevalensi berkurang dan komplikasi dapat dihindari. Diabetes melitus tipe 2 ditandai dengan defisiensi insulin relatif yang disebabkan oleh disfungsi sel pankreas dan resistensi insulin. Faktor risiko penyebabnya dibagi menjadi dua yaitu faktor risiko yang dapat dimodifikasi dan tidak dapat dimodifikasi. Gejala klasik diabetes seperti poliuria, polidipsia, polifagia dan penurunan berat badan yang tidak dapat dijelaskan sebabnya. Empat tes diagnostik untuk diabetes yaitu pengukuran glukosa plasma puasa, glukosa plasma 2 jam setelah TTGO $75 \mathrm{~g}$, HbA1c, dan glukosa darah acak dengan adanya tanda dan gejala klasik diabetes. Tatalaksana dibagi menjadi dua, yaitu farmakologi dan non farmakologi. Tatalaksana non farmakologis terdiri atas edukasi, nutrisi medis, dan latihan fisik. Terapi farmakologis terdiri atas obat oral dan bentuk suntikan dalam bentu obat anti hiperglikemik dan insulin. Terapi farmakologi dan non farmakologi ini berjalan beriringan.
\end{abstract}

Kata Kunci: Diabetes melitus, faktor risiko, diagnosis, tatalaksana

\begin{abstract}
Diabetes mellitus describes a group of metabolic diseases whose common finding is elevated blood glucose levels. At the age of $20-79$ years, there were 463 million or $9.3 \%$ of people in the world suffer from diabetes in 2019. The writing of this article uses the literature review method and is expected to be used as a future reference in carrying out prevention and treatment of diabetes mellitus patients so that prevalence is reduced and complications can be avoided. Type 2 diabetes mellitus is characterized by relative insulin deficiency caused by pancreatic cell dysfunction and insulin resistance. The risk factors that cause it are divided into two, namely modifiable and non-modifiable risk factors. The classic symptoms of diabetes include polyuria, polydipsia, polyphagia and unexplained weight loss. The four diagnostic tests for diabetes are measurement of fasting plasma glucose, plasma glucose 2 hours after OGTT $75 \mathrm{~g}, \mathrm{HbA} 1 \mathrm{c}$, and randomized blood glucose in the presence of classic signs and symptoms of diabetes. Treatment is divided into two, namely pharmacological and non-pharmacological. Non-pharmacological management consists of education, medical nutrition, and physical exercise. Pharmacological therapy consists of oral drugs and injections in the form of antihyperglycemic drugs and insulin. Pharmacological and non-pharmacological therapy goes hand in hand.
\end{abstract}

Keywords: Diabetes mellitus, risk factors, diagnosis, management 


\section{PENDAHULUAN}

Sebanyak 41 juta orang meninggal dunia karena Penyakit Tidak Menular (PTM) atau setara dengan $71 \%$ dari semua kematian di dunia setiap tahunnya. Terdapat 15 juta orang lebih dengan rentang usia 30 sampai 69 tahun meninggal karena PTM, 85\% diantaranya berasal dari negara yang memiliki penghasilan menengah kebawah. Empat penyakit yang berkontribusi besar dalam kematian PTM ini antara lain, penyakit kardiovaskuler sebanyak 17,9 juta orang, penyakit kanker sebanyak 9,3 juta orang, penyakit pernapasan sebanyak 9,3 juta orang, dan diabetes sebanyak 1,5 juta orang setiap tahunnya (1). Diabetes melitus tipe 2 merupakan krisis global yang mengancam kesehatan dan perekonomian dunia. Sekitar 1 dari setiap 11 orang dewasa menderita DM tipe 2 secara global, dan sekitar $75 \%$ pasien diabetes melitus tinggal di negara berkembang (2).

Organisasi International Diabetes Federation (IDF) memperkirakan bahwa pada kelompok usia 20-79 tahun, terdapat 463 juta orang di dunia menderita diabetes pada tahun 2019 atau sama dengan 9,3\% dari jumlah total penduduk pada usia tersebut. Di Asia Tenggara, dimana Indonesia salah satu negara di dalamnya, menempati peringkat ke-3 dengan jumlah penderita diabetes melitus sebesar 11,3\%. Indonesia meraih peringkat 7 dari 10 jumlah penderita terbanyak dengan jumlah 10,7 juta orang (3). Prevalensi diabetes melitus meningkat dari $6,9 \%$ menjadi $10,9 \%$ pada penduduk usia $\geq 15$ tahun (4).

Diabetes melitus menggambarkan sekelompok penyakit metabolik, yang temuan umumnya adalah kadar glukosa darah yang meningkat, yang dikenal sebagai hiperglikemia. Hiperglikemia berat dapat menimbulkan gejala seperti poliuria, polidipsia, polifagia, penurunan berat badan yang tidak dapat dijelaskan, kelelahan dan penurunan kinerja, gangguan penglihatan dan rentan terhadap infeksi ketoasidosis atau nonketoasidosis. Hiperglikemia kronis juga menyebabkan gangguan sekresi dan/atau kerja insulin serta dikaitkan dengan kerusakan jangka panjang dan gangguan fungsional berbagai jaringan dan organ (5).

Klasifikasi saat ini untuk diabetes melitus dibagi menjadi dua yaitu diabetes melitus tipe 1 dan tipe 2. Selanjutnya, kriteria untuk diagnosis biokimia yang dipakai yaitu pengukuran glukosa darah selama puasa dan tes toleransi glukosa oral serta penggunaan hemoglobin A1C (HbA1c) (5). Diabetes adalah krisis global yang terutama didorong oleh urbanisasi yang cepat, gaya hidup yang berubah, dan pola makan yang tidak merata. Sangat penting untuk memprediksi prevalensi diabetes pada individu untuk mengurangi risiko perkembangan diabetes melitus dan menyelamatkan nyawa pasien.

Diabetes diperkirakan terjadi karena beberapa faktor risiko seperti asam urat serum tingkat tinggi, kualitas/kuantitas tidur yang buruk, merokok, depresi, penyakit kardiovaskular, dislipidemia, hipertensi, penuaan, etnis, riwayat keluarga diabetes, ketidakaktifan fisik, dan obesitas (6). Keseimbangan kalori yang tidak baik dari kebiasaan diet yang tidak sehat, penurunan aktivitas fisik, dan peningkatan kegiatan yang menggunakan energi yang sedikit menyebabkan peningkatan adipositas, yang pada akhirnya menyebabkan pembentukan kembali jaringan adiposa dan obesitas. Kelebihan adipositas ini, pada gilirannya, secara nyata meningkatkan risiko penyakit kardiometabolik, terutama diabetes melitus tipe 2 (7). Selain itu, kebiasaan merokok juga berhubungan, perokok aktif dan pasif sangat terkait dengan kejadian diabetes tipe 2 (6).

Rekomendasi gaya hidup untuk menyeimbangkan kalori dengan aktivitas fisik sangatlah bijaksana untuk saat ini (8). Faktor risiko paling menonjol adalah obesitas yang lebih sering terjadi pada perempuan. Perkembangan, predisposisi, dan gejala klinis antara laki-laki dan perempuan dipengaruhi oleh beberapa hal, seperti perbedaan gaya hidup, lingkungan, biologis, dan sosial ekonomi (9).

Penulisan artikel ini bertujuan untuk membahas mengenai faktor risiko, diagnosis, dan tatalaksana dari diabetes melitus sebagai penyakit tidak menular 
dengan prevalensi cukup tinggi di dunia dengan dampak yang serius apabila dibiarkan tanpa diberikan tatalaksana yang tepat. Diharapkan, artikel ini dijadikan sebagai acuan kedepan dalam melakukan tindakan pencegahan dan pengobatan pasien diabetes melitus tipe 2 sehingga prevalensi berkurang dan komplikasi dapat dihindari.

\section{METODE}

Artikel ini ditulis menggunakan metode literature review atau tinjauan pustaka. Penulisan artikel ini mengambil sumber dari artikel, jurnal, dan web resmi (WHO, Kemenkes) yang berkaitan dengan artikel yang dibuat yaitu terkait faktor risiko, diagnosis, dan tatalaksana dari diabetes melitus tipe 2. Artikel dan jurnal penelitian didapat dari hasil pencarian menggunakan kata kunci yang telah ditetapkan pada platform Google Scholar, Science Direct, dan Pubmeds. Sumber yang dipilih merupakan sumber yang dipublikasikan minimal 10 tahun terakhir.

\section{HASIL DAN PEMBAHASAN}

Diabetes Melitus (DM) tipe 2 ditandai dengan defisiensi insulin relatif yang disebabkan oleh disfungsi sel beta pankreas dan resistensi insulin pada organ target (10). DM tipe 2 disebabkan oleh karena adanya kelainan dalam sekresi insulin, cara kerja insulin, ataupun kelainan pada keduanya (11). DM tipe 2 terjadi dikaitkan dengan beberapa organ pada tubuh, yang dikenal dengan istilah ominous octet yaitu kegagalan sel beta pankreas dalam mensekresikan insulin yang cukup dalam upaya mengompensasi peningkatan resistensi insulin (11).

\section{a. Faktor Risiko}

Terdapat dua pembagian faktor risiko yang dapat memicu kejadian diabetes melitus, antara lain faktor risiko yang dapat dimodifikasi (di ubah) dan tidak dapat di modifikasi. Faktor risiko yang dapat dimodifikasi antara lain obesitas atau berat badan lebih dengan IMT $\geq 23 \mathrm{~kg} / \mathrm{m}^{2}$, hipertensi dengan tekanan darah $>140 / 90 \mathrm{mmHg}$, aktivitas fisik kurang, dislipidemia dengan kadar $\mathrm{HDL}<35 \mathrm{mg} / \mathrm{dL}$ dan/atau trigliserida $>250$ $\mathrm{mg} / \mathrm{dL}$, mengonsumsi makanan yang tidak sehat, mengandung tinggi glukosa dan rendah serat dapat memberikan peluang tinggi untuk menderita intoleransi glukosa atau prediabetes dan DM tipe 2 . Sedangkan beberapa faktor risiko yang tidak dapat dimodifikasi, seperti usia, jenis kelamin, riwayat keluarga menderita diabetes melitus, ras dan etnis, pernah melahirkan bayi dengan berat badan lahir bayi lebih dari $4 \mathrm{~kg}$ atau memiliki riwayat menderita diabetes melitus gestasional, riwayat lahir dengan berat badan rendah kurang dari 2500 gram (11)(12). Berbagai macam faktor gaya hidup juga sangat penting untuk perkembangan DM tipe 2, seperti kurangnya aktivitas fisik, kebiasaan merokok, dan sering mengonsumsi alkohol. Pada studi epidemiologis substansial menunjukkan bahwa obesitas adalah faktor risiko terpenting untuk DM tipe 2, yang dapat mempengaruhi perkembangan penyakit dan resistensi insulin (13) (2).

Seiring meningkatnya usia, maka risiko untuk menderita intoleransi glukosa juga meningkat. Pada jenis kelamin, wanita lebih berisiko karena dilihat secara fisik wanita memiliki peluang yang lebih tinggi dalam peningkatan IMT (Indeks Massa Tubuh). Selain itu, sindrom sebelum menstruasi dan setelah menopause dapat mengakibatkan distribusi lemak tubuh terganggu sehingga mudah terakumulasi dan dapat meningkatkan risiko wanita menderita DM tipe 2 (14). Memiliki keluarga seperti ibu, ayah, dan saudara kandung yang menderita DM dapat meningkatkan risiko menderita DM (15). Obesitas merupakan penumpukan lemak di dalam tubuh yang dikarenakan oleh ketidak seimbangan antara jumlah kalori yang masuk dan kalori yang ke luar tubuh. Lebih tinggi kalori masuk dibandingkan dengan kalori yang ke luar disebabkan oleh kurangnya aktivitas fisik yang dilakukan sehingga lemak menumpuk di tubuh dan meningkatkan risiko diabetes melitus tipe 2. (16). Pada perokok, cenderung memiliki akumulasi lemak sentral daripada bukan perokok, dan perokok diketahui memiliki resistensi insulin dan respons sekresi insulin kompensasi yang dapat 
menjelaskan peningkatan risiko DM tipe 2 pada orang yang merokok (2).

Manifestasi klinis dari penyandang diabetes melitus dapat dibagi menjadi dua yaitu gejala klinis klasik dan gejala umum. Gejala klasik dari diabetes melitus adalah 4P (Polidipsia, Polifagia, Poliuria, dan Penurunan berat badan yang penyebabnya tidak dapat dijelaskan). Sedangkan gejala umum antara lain kelelahan, kegelisahan, nyeri tubuh, kesemutan, mata kabur, gatal, dan disfungsi ereksi pada pria, serta pruritus vulva pada wanita (11).

\section{b. Diagnosis}

Empat tes diagnostik untuk diabetes yang direkomendasikan saat ini, yaitu pengukuran glukosa plasma puasa, glukosa plasma 2 jam setelah TTGO $75 \mathrm{~g}$, $\mathrm{HbA1c}$, dan glukosa darah acak dengan adanya tanda dan gejala klasik diabetes. Orang dengan nilai glukosa plasma puasa $\geq 7,0 \mathrm{mmol} / \mathrm{L}$ (126 mg/dL), glukosa plasma pasca-beban 2 jam $\geq 11,1 \mathrm{mmol} / \mathrm{L}$ (200 $\mathrm{mg} / \mathrm{dL}), \quad \mathrm{HbA} 1 \mathrm{c} \geq 6,5 \%(48 \mathrm{mmol} / \mathrm{mol})$, atau glukosa darah acak $\geq 11,1 \mathrm{mmol} / \mathrm{L}$ (200) $\mathrm{mg} / \mathrm{dL}$ ) dengan adanya tanda dan gejala klasik dianggap menderita diabetes. Pada seseorang yang tidak memiliki gejala tetapi nilai tesnya meningkat, maka disarankan untuk melakukan pengujian ulang dengan tes yang sama sesegera mungkin agar diagnosis dapat dipastikan (17).

\section{c. Tatalaksana}

Tujuan terapi DM tentunya untuk mengurangi risiko komplikasi jangka pendek dan jangka panjang. Terapi obat memiliki efek menguntungkan pada risiko komplikasi, tetapi tidak cukup untuk membalikkannya. Indikasi terkuat yang dibagikan oleh pedoman terbaru dan dokumen konsensus tentang pengelolaan penyakit diabetes membutuhkan perhatian terus menerus untuk penerapan gaya hidup yang benar dan perlunya personalisasi terapi, dengan adaptasi farmakologis dan non-farmakologis (terapi nutrisi, latihan fisik) dengan profil metabolik dan klinis pasien individu (18).

Tatalaksana non farmakologis terdiri atas edukasi, nutrisi medis, dan latihan fisik. Edukasi dilakukan dengan tujuan untuk promosi kesehatan, sebagai bagian dari upaya pencegahan dan pengelolaan DM secara holistik. Contohnya saja seperti cara merawat luka pada kaki yang terdapat ulkus dan selalu menggunakan alas kaki. Selanjutnya nutrisi medis, sama seperti anjuran makan untuk masyarakat umum, anjuran makan bagi penderita DM adalah makanan seimbang yang menyesuaikan dengan zat gizi dan kebutuhan kalori dari masing-masing individu. Penderita DM perlu diberikan edukasi mengenai betapa pentingnya keteraturan terhadap jenis makanan, jadwal makan, dan jumlah kalori yang terkandung dalam makanannya, terlebih pada penderita DM yang mengonsumsi obat-obatan yang berfungsi untuk meningkatkan sekresi insulin atau menggunakan terapi insulin. Komposisi karbohidrat $45-65 \%$, lemak $20-25 \%$, dan protein $30-35 \%$, menggunakan pemanis tak berkalori. Ketiga adalah latihan fisik. Program latihan fisik secara teratur selama sekitar 30-45 menit sehari, dilakukan 3-5 hari dalam seminggu, dan total per minggu yaitu 150 menit. Usahakan jeda tidak lebih dari 2 hari berturut-turut antara dua latihan. Latihan fisik yang dianjurkan untuk penderita DM adalah latihan fisik dengan intensitas sedang dan bersifat aerobik seperti jogging, jalan cepat, bersepeda santai, dan berenang (11) .

Terapi farmakologis pada DM tipe 2 diberikan beriringan dengan pengaturan pola makan, latihan fisik, dan gaya hidup sehat. Terapi farmakologis terdiri atas obat yang diminum oral dan bentuk suntikan. Berikut adalah obat antidiabetes non-insulin umum antara lain golongan biguanida. Biguanida adalah salah satu kelas utama obat antidiabetes, di antaranya metformin. Metformin merupakan obat paling umum dan menjadi lini pertama untuk penderita DM dan telah terbukti bermanfaat dalam mengurangi angka kematian akibat DM tipe 2 karena dapat meningkatkan sensitivitas insulin, menurunkan glukosa darah, menekan risiko hipoglikemia dan kardiovaskuler serta merupakan satusatunya agen hipoglikemik untuk meningkatkan hasil makrovaskular (19). Sulfonilurea merupakan obat yang banyak 
digunakan sebagai terapi lini kedua dalam pengobatan pasien DM tipe 2 yang tidak mengalami obesitas berat, yang bekerja langsung pada sel pulau untuk menutup saluran $\mathrm{K}+$ yang sensitif terhadap ATP dan merangsang sekresi insulin.

Thiazolidinediones atau TZDs adalah kelas sensitizer insulin, termasuk zona troglita, rosiglitazone, dan pioglitazone. Mereka merupakan ligan peroxisome proliferator-activated receptor (PPAR- $\gamma$ ) yang mengontrol otot rangka normal dan sensitivitas insulin hati. Glucosidase inhibitors (AGIs), termasuk acarbose, voglibose dan miglitol, sangat efektif untuk hiperglikemia postprandial. Mereka dapat menghambat enzim mukosa usus (a-glucosidase) yang mengubah kompleks polisakarida menjadi monosakarida, sehingga dapat mengurangi penyerapan karbohidrat. Terapi berbasis inkretin, Inkretin adalah hormon yang merangsang sekresi insulin dan menekan sekresi glukagon postprandial dengan cara yang bergantung pada glukosa. Agonis reseptor GLP-1, termasuk exenatide dan liraglutide, dapat menurunkan kadar hemoglobin A1c ( $\mathrm{HbA1c})$ sebesar $0,8 \%$ menjadi 1,5 (13) (12).

Dengan berbagai kemungkinan terapi antidiabetik oral dengan atau tanpa kombinasi dengan GLP-1-RA, terapi insulin dalam banyak kasus dapat ditunda ke tahap penyakit selanjutnya. Namun, pemberian insulin yang diperlukan tidak boleh ditunda selama bertahun-tahun. Terapi insulin dapat dengan mudah dikombinasikan dengan obat antidiabetes lainnya, dan sejumlah besar insulin dan alat bantu injeksi memfasilitasi individualisasi terapi (12). Jenis dan lama kerja insulin berbeda-beda, insulin terbagi menjadi 5 jenis, yakni: insulin kerja cepat, insulin kerja pendek, insulin kerja menengah, insulin kerja panjang, insulin kerja ultra panjang, dan insulin campuran tetap, kerja pendek dengan menengah dan kerja cepat dengan menengah (premixed insulin).

Komplikasi diabetes melitus dibagi menjadi komplikasi makrovaskular (misalnya, penyakit kardiovaskular (CVD)) dan komplikasi mikrovaskular (misalnya, komplikasi yang mempengaruhi ginjal, retina dan sistem saraf) (2). CVD, termasuk penyakit jantung koroner, penyakit pembuluh darah perifer dan penyakit serebrovaskular, adalah penyebab utama morbiditas dan mortalitas di Amerika Serikat. Sekitar 10\% kematian pada orang dengan DM tipe 2 disebabkan oleh gagal ginjal. Prevalensi retinopati diabetik adalah sekitar $28,5 \%$ di Amerika Serikat dan berkisar antara 16\% hingga $35 \%$ di negara-negara Asia. DM tipe 2 adalah penyebab utama amputasi tungkai bawah non-trauma di Amerika Serikat. Di Inggris, sekitar satu dari tiga orang yang diamputasi menderita diabetes melitus (2).

\section{KESIMPULAN}

Diabetes melitus merupakan penyakit metabolik yang temuan umumnya adalah kadar glukosa darah yang meningkat. Sekitar 1 dari setiap 11 orang dewasa menderita DM tipe 2 secara global, dan sekitar $75 \%$ pasien diabetes mellitus tinggal di negara berkembang (2). Diabetes melitus tipe 2 ditandai dengan defisiensi insulin relatif yang disebabkan oleh disfungsi sel pankreas dan resistensi insulin. Faktor risikonya dapat dimodifikasi dan tidak dapat dimodifikasi. Tatalaksana dibagi menjadi dua, yaitu farmakologi dan non farmakologi. Tatalaksana non farmakologis terdiri atas edukasi, nutrisi medis, dan latihan fisik. Terapi farmakologis terdiri atas obat oral dan bentuk suntikan dalam bentuk obat anti hiperglikemik dan insulin. Terapi farmakologi dan non farmakologi ini berjalan beriringan agar prevalensi DM tipe 2 dapat berkurang dan komplikasi dapat dihindari.

Kasus DM tipe 2 ini dapat dicegah dengan menghindari faktor risiko yang dapat dimodifikasi seperti menjaga berat badan yang sehat dengan fokus menjaga keseimbangan energi dengan melakukan aktivitas fisik secara teratur dan mengonsumsi makanan yang sehat. Mencegah dan mengelola diabetes melitus gestasional untuk menghentikan lingkaran setan di mana diabetes melitus dapat melahirkan diabetes melitus. Untuk manajemen DM tipe 2, modifikasi gaya hidup, dukungan sosial, dan kepatuhan 
pengobatan penting dilakukan untuk menghindari komplikasi makrovaskular dan mikrovaskular.

\section{DAFTAR PUSTAKA}

WHO. Noncommunicable diseases [Internet]. 2018 [cited 2021 Apr 4]. Available from: https://www.who.int/newsroom/factsheets/detail/noncommunicablediseases

Zheng Y, Ley SH, Hu FB. Global aetiology and epidemiology of type 2 diabetes mellitus and its complications. Nat Rev Endocrinol [Internet]. 2018;14(2):88-98. Available from: http://dx.doi.org/10.1038/nrendo.20 17.151

Kementrian Kesehatan RI. Infodatin: Tetap Produktif, Cegah, dan Atasi Diabetes Melitus. 2020.

Direktorat Jenderal Pencegahan dan Pengendalian Penyakit. Buku Pedoman Penyakit Tidak Menular. Kementeri Kesehat RI [Internet]. 2019;101. Available from: http://p2ptm.kemkes.go.id/uploads/ VHcrbkVobjRzUDN3UCs4eUJ0dVB ndz09/2019/03/Buku_Pedoman_Ma najemen_PTM.pdf

Harreiter J, Roden M. Diabetes mellitusDefinition, classification, diagnosis, screening and prevention (Update 2019). Wien Klin Wochenschr. 2019;131(Update):6-15.

Ismail L, Materwala $\mathrm{H}$, Kaabi $\mathrm{J}$ Al. Association of Risk Factors with Type 2 Diabetes: A Systematic Review. Comput Struct Biotechnol J [Internet]. 2021; Available from: https://doi.org/10.1016/j.csbj.2021.0 3.003

Carbone S, Del Buono MG, Ozemek C, Lavie CJ. Obesity, risk of diabetes and role of physical activity, exercise training and cardiorespiratory fitness. Prog Cardiovasc Dis [Internet]. 2019;62(4):327-33. Available from: https://doi.org/10.1016/j.pcad.2019. 08.004

Rice Bradley BH. Dietary Fat and Risk for
Type 2 Diabetes: a Review of Recent Research. Curr Nutr Rep. 2018;7(4):214-26.

Kautzky-Willer A, Harreiter J, Pacini G. Sex and gender differences in risk, pathophysiology and complications of type 2 diabetes mellitus. Endocr Rev. 2016;37(3):278-316.

Chatterjee S, Khunti K, Davies MJ. Type 2 diabetes. Lancet [Internet]. 2017;389(10085):2239-51.

Available from: http://dx.doi.org/10.1016/S01406736(17)30058-2

Parkeni. Konsesus Pengelolaan Dan Pencegahan Diabetes Melitus Tipe2 Di Indonesia 2015 [Internet]. Perkeni. 2015. 82 p. Available from: https://www.google.com/url?sa=t\&s ource=web\&rct=j\&url=https://pbperk eni.or.id/wp-

content/uploads/2019/01/4.-

Konsensus-Pengelolaan-dan-

Pencegahan-Diabetes-melitus-tipe2-di-Indonesia-PERKENI2015.pdf\&ved=2ahUKEwjy8KOs8cf oAhXCb30KHQb1Ck0QFjADegQIB $\mathrm{hAB} \& u s g=\mathrm{AOv}$

Landgraf $\mathrm{R}$, Aberle J, Birkenfeld AL, Gallwitz B, Kellerer M, Klein HH, et al. Therapy of type 2 diabetes. Exp Clin Endocrinol Diabetes. 2019;127(1):S73-92.

Wu Y, Ding Y, Tanaka Y, Zhang W. Risk factors contributing to type 2 diabetes and recent advances in the treatment and prevention. Int $\mathrm{J}$ Med Sci. 2014;11(11):1185-200.

Setyorogo S, Trisnawati S. Faktor Resiko Kejadian Diabetes Melitus Tipe II Di Puskesmas Kecamatan Cengkareng Jakarta Barat Tahun 2012. J Ilm Kesehat. 2013;5(1):611.

Isnaini N, Ratnasari R. Faktor risiko mempengaruhi kejadian Diabetes mellitus tipe dua. $\mathbf{J}$ Kebidanan dan Keperawatan Aisyiyah. 2018;14(1):59-68.

Utomo AA, Aulia A, Rahmah S, Amalia R. Faktor Risiko Diabetes Mellitus Tipe 2: A Systematic Review. J Kaji dan Pengemb Kesehat Masy [Internet]. 2020;1(1):44-52. Available from: https://jurnal.umj.ac.id/index.php/A 


\section{$\mathrm{N}-\mathrm{NUR}$}

WHO. Classification of diabetes mellitus. Vol. 21, Clinics in Laboratory Medicine. 2019.

Cannata F, Vadalà G, Russo F, Papalia R, Napoli N, Pozzilli P. Beneficial effects of physical activity in diabetic patients. J Funct Morphol Kinesiol. 2020;5(3).

Sanchez-Rangel E, Inzucchi SE. Metformin: clinical use in type 2 diabetes. Diabetologia. 2017;60(9):1586-93. 